\title{
Colonised as Coloniser: Historiography of Indian Writings on South East Asian Archaeology during Early Twentieth Century
}

\author{
Kishor K Basa* \\ Department of Anthropology, Utkal University, India \\ Submission: April 23, 2018; Published: June 12, 2018 \\ *Corresponding author: Kishor K Basa, Department of Anthropology, Utkal University, Bhubaneswar, India, Email: kishorkbasa58@gmail.com
}

Keywords: Archaeology; Historiography; Colonizer; Nationalism; Orientalists; Suvarnabhumi; Civilizing mission; Democracy; Civilization; Suvarnadvipa; Cultural heritage; Golden age; Romanticists;

During the last three decades there has been a proliferation of works on archaeology and nationalism [1]. It is not merely because of the upsurge of nationalist movements and conflicts throughout the world, but also because of the development internal to the practice of archaeology and advances in the broader historical study on nationalism [2]. In the history of archaeology the colonial and nationalist perspectives are generally portrayed as a binary [3]. This has limited the linkage between nationalism and archaeology. The present paper therefore problematises such a linkage by emphasizing how a colonized was also a colonizer taking into account the Indian writings on South East Asian early history and archaeology during the first half of twentieth century.

\section{Colonial and Nationalist Perspectives}

The formation of the Asiatic Society of Bengal in 1784 with Sir William Jones as its founder President resulted in the discovery of sublime aspects of Indian heritage which led to the construction of the canon of Orientalism based on the assumption that India had possessed a great civilization in antiquity, but had subsequently fallen into stagnation and decline [4]. On the contrary, James Mill during early nineteenth century wrote 'History of India' which had a disparaging attitude towards India. The Romanticists like the Orientalists, celebrated India's past and considered India of early nineteenth century representing 'the adolescence of Europe'. All the colonial perspectives provided legitimacy to British rule in India. While the disparaging attitude of James Mill towards India provided enough justification for continuation of colonial rule since it was supposed to be more progressive, for the Orientalists and romanticists, the British rule in India was a 'civilizing mission' and a harbinger of democracy and science.

From the days of Partition of Bengal (1905) the nationalist movement gained momentum in India. The emergence of
Gandhi in the scene made a distinct impact. Especially the NonCooperation Movement in 1921 demonstrated the potentiality of a non-violent mass movement and India attained freedom in 1947. In the background of Indian freedom movement, the Indian nationalist school of historiography emerged as an ideological tool to counteract colonial historiography [5] by arguing that India had a golden age in ancient India, Indian civilization was much older than the western civilization and that the western virtues of democracy and science were not unknown to India in antiquity. Hence Indians did not need the colonial rule.

\section{Indian Nationalist School on South East Asian Archaeology}

In its contestation of colonial historiography, the Indian nationalist school used South East Asian history and archaeology also. Hence the intensification of Indian freedom movement during 1920s-40s and the formation of Greater India Society in 1926 in Kolkata as well as the launching of the Journal of Greater India Society in 1934 cannot be regarded as a mere coincidence [6]. The aims and objectives were made explicit by Rabindranath Tagore in his Foreword to the first number:

"To know my country in truth one has to travel to that age when she realized her soul, and thus transcended her physical boundaries, when she revealed her being in a radiant magnanimity which illumined the Eastern horizon making her recognized as their own by those in alien shore who were awakened into a great surprise of life ----“ (1934:Foreword).

The leading Indian scholars who published on South East Asian archaeology during that period were R. C. Majumdar, Nilakanta Sastri KA, Chhabra BC, Sarkar HB, Chatterji BC, Ray NR, Gangoly BC etc. [7]. A term persistently used was 'colony' although none defined it. On the basis of their writings, one can mention three forms of colony - commercial, political and 
cultural. What was at first commercial intercourse was followed by political influence [8] and cultural conquest [9]. The most concrete evidence of the establishment of Indian kingdoms in South East Asia came in the form of inscriptions found in South East Asia. According to Majumdar, "colonization, as distinguished from the establishment of political authority, evidently took place much earlier and the beginnings of trade intercourse which must have preceded colonization may thus be placed centuries before the Christian Era". The causes of Indian 'colonization' included the lure of acquiring wealth, the missionary zeal of Brahmins and Buddhists, pressure caused by increasing population and invasion by foreign hordes, the spirit of adventure of Ksatriya princes and nobles and the commercial enterprise of merchants [10]. South East Asia, famous for spices, was known as Suvarnabhumi or Suvarnadvipa, meaning the land of gold and hence "the Indians were attracted to the East by the same allurements which proved irresistible to the Arabs in the ninth and tenth and to the Europeans in the fifteenth and sixteenth centuries A.D." [10].

The Indian nationalist scholars argued that India had influenced every sphere of South East Asian culture, i. e. writing, art, literature, sculpture, architecture, society and religion, a process known as 'Indianisation' which Coedes defined as "the expansion of an organized culture that was founded upon the Indian conception of royalty, was characterized by Hinduist or Buddhist cults, the mythologies of the Puranas, and the observance of the Dharmasastras, and expressed in Sanskrit language" Writing in 1914 Mookerji stated, "the colonising activity resulted in the practical "Indianisation' of the countries touched by it - the transplantation and in some cases reproduction, of Indian art, institution and even geographical names". Talking of South East Asia, Majumdar wrote, "Indianisation of these countries was primarily as complete in the ancient times as we find in the Dravidian countries within the frontier of India". In an exaggerated version some of the best specimens of South East Asia were believed to be the works of Indian artisans [11]. At its extreme even Barabudur was regarded as the product of Indian craftsmanship [12]. As Gangoly said, "the art and civilization of Java formed an integral part of art and civilization of the Indian continent. It is one of the outlying frontiers of the Civilization of a Greater India stretching itself to the shores beyond 'the moving seas'.

\section{Colonised as Coloniser}

In relation to British colonial scholars, the Indian nationalist school represented the colonized India and in that sense represented a liberating dimension by providing legitimacy to the anti-colonial freedom struggle in India. Its proponents argued that much before the British 'colonized' India, the latter had her 'colonies' in South East Asia, known as 'Greater India'. As R. K. Mookerji wrote in 1914, "there can hardly be a more convincing proof of the reality and strength of the Indian unity than the story of Indian colonizing activity and the gradual development of a
Greater India across the seas". Thus the Indians did not require the British colonial 'civilizing mission', because not only were the former themselves already 'civilized' from the remote past, they had also carried out the 'civilizing mission' in South East Asia, much earlier than any western power. By implication this means that the nationalist school did not challenge the principle of domination of the Third World by Western colonial powers. Moreover, while the scholars of the Indian nationalist school emphasized indigenous evolution as an important factor of culture change within India, in relation to South East Asia, they stressed on the diffusion of ideas, artifacts and intellects from India as the main reason of progress. This means that Indian nationalist writings on South East Asia turned out to be colonial writings for South East Asia. This is the major limitation [13-16]. For example, R. C. Majumdar mentioned that Champa was "one of the many colonial kingdoms" which Indians had set up in the Far East. It may be argued that the terms 'Greater India' and 'Indian Colonies' were used by western colonial scholars on South East Asia, and hence these terms were not the coinage of the Indian nationalist school. But the problem is use of such terms may be consistent with the Western colonial historiography since it represented colonial powers. But by the uncritical use of these terms by the proponents of Indian nationalist school in their writings on South East Asia, they fell into the trap they wanted to avoid, that is colonial historiography. The second limitation was that the Indian nationalist scholars in their extreme view did not consider South East Asians as active agents, but passive recipients of social processes. In other words, the 'colonised' in its sincere attempt to contest and counteract the 'coloniser' became a 'coloniser' itself. This is the greatest irony of the Indian nationalist historiography of the colonial period. It is because of this that during the post-colonial period emphasis has been given by Indian scholars on the shared cultural heritage and complimentary relationship of the two regions as well as the active role played by South East Asia in the making of a South East Asian personality.

\section{References}

1. Kohl P (1998) Nationalism and archaeology: constructions of nations and the reconstructions of the remote past. Annual Review of Anthropology 27: 233-46.

2. Trigger B (1989) A History of Archaeological Thought. Cambridge University Press, Cambridge, USA.

3. Chakrabarti DK (1997) Colonial Indology: Sociopolitics of the Ancient Indian Past. Delhi, India.

4. Asher CB, Metcalf TR (1994) Introduction. In pp 1-12 Perceptions of South Asia's Visual Past edited by Asher and Metcalf, Oxford \& IBH, New Delhi, India.

5. Majumdar RC (1961) Nationalist historians; In: Philips CH(Eds.),Historians of India, Pakistan and Ceylon; Oxford University Press, London, UK, pp. 416-28.

6. Tagore RN (1934) Foreword in Journal of the Greater India Society.

7. Basa KK (1998) Indian writings on early history and archaeology of Southeast Asia: A historiographical analysis. Journal of the Royal Asiatic Society London, UK 8(3): 395-410. 
8. Chatterjee BR (1939) Recent advances in Kambuja studies. Journal of the Greater India Society 6(2): 138-45.

9. Majumdar RC (1927) Ancient Indian Colonies in the Far East, Vol. 1 Punjab Sanskrit Book Depot, Lahore.

10. Majumdar RC (1944) Hindu Colonies in the Far East. General printers and Publishers, Calcutta, India.

11. Nilakanta Sastri KA (1941) Srivijaya. Bulletin de l'Ecole Francaise d'Extreme-Orient XL(2): 239-310.

12. Gangoly OC (1927) The Art of Java. Rupam, Calcutta, India.
13. Basa KK (1991) The Westerly Trade South East Asia with Special Reference to Glass Beads. University of London, UK.

14. Basa KK (2007) Social Theory and Indian Archaeology: A Historiographical Study during the Colonial Period. Presidential address, Archaeology Section, Indian History Congress $\left(67^{\text {th }}\right.$ session, Kozhikode).

15. Coedes G (1968) The Indianised States of South East Asia. East and West Center Press, Hawaii, USA

16. Mookerji RK (1954) The Fundamental Unity of India. Bharatiya Vidya Bhavan, Bomnay,Maharashtra, India.

\section{Your next submission with Juniper Publishers will reach you the below assets}

- Quality Editorial service

- Swift Peer Review

- Reprints availability

- E-prints Service

- Manuscript Podcast for convenient understanding

- Global attainment for your research

- Manuscript accessibility in different formats

( Pdf, E-pub, Full Text, Audio)

- Unceasing customer service

Track the below URL for one-step submission

https://juniperpublishers.com/online-submission.php 